\title{
Mechanisms of Induced Resistance in Barley Against Drechslera teres
}

\author{
H. J. Lyngs Jørgensen, P. Stephensen Lübeck, H. Thordal-Christensen, E. de Neergaard, and V. Smedegaard-Petersen
}

Plant Pathology Section, Department of Plant Biology, The Royal Veterinary and Agricultural University, Thorvaldsensvej 40, DK-1871 Frederiksberg C, Copenhagen, Denmark.

Accepted for publication 24 March 1998.

\begin{abstract}
Jørgensen, H. J. L., Lübeck, P. S., Thordal-Christensen, H., de Neergaard, E., and Smedegaard-Petersen, V. 1998. Mechanisms of induced resistance in barley against Drechslera teres. Phytopathology 88:698-707.

Quantitative and qualitative histopathological methods and molecular analyses were used to study the mechanisms by which preinoculation with either of the nonbarley pathogens, Bipolaris maydis and Septoria nodorum, inhibited growth of Drechslera teres. Collectively, our data suggest that induced resistance is the principal mechanism responsible for impeding the pathogen. The enhancement of resistance in the host was primarily manifested during penetration by $D$. teres, and after penetration, where growth of $D$. teres ceased soon after development of infection vesicles. Thus, $24 \mathrm{~h}$ after pretreatment with $B$. maydis or $S$. nodorum, the penetration frequency from $D$. teres appressoria was re-

duced from $42.7 \%$ in the controls to 9.5 and $14.8 \%$, respectively. The reductions were associated with increased formation of fluorescent papillae in induced cells (early defense reaction). The postpenetrational inhibition of $D$. teres completely stopped fungal growth and was apparently linked to an enhancement of multicellular hypersensitive responses in inducer-treated leaves (late defense reaction). Papillae formation and multicellular hypersensitive reactions were also observed in fully susceptible, noninduced control leaves, but they were inadequate to stop fungal progress. Northern blots from leaves treated with either inducer alone support the conclusion that induced resistance is involved in suppression of $D$. teres by increased formation of papillae and hypersensitive reactions. Thus, the blots showed strong expression of several defense response genes that are involved in these reactions in barley attacked by Erysiphe graminis f. sp. hordei.
\end{abstract}

Induced or acquired resistance against biotrophic pathogens in barley and other grasses is a well-known phenomenon that has been studied intensely $(31,32,36)$. On the other hand, induced resistance against necrotrophic pathogens in monocotyledonous plants has apparently not been examined to any great extent, with a few exceptions such as the rice-Pyricularia oryzae system $(2,23,33)$.

In a previous report (14), the severity of barley net blotch caused by the necrotrophic pathogen Drechslera teres and hyphal growth in the host tissue was shown to be strongly reduced when the leaves were pretreated with conidial suspensions of either of the two nonbarley pathogens, Bipolaris maydis from maize or Septoria nodorum from wheat. The results suggested that induced resistance was involved, but detailed studies of the mechanisms responsible were not carried out. Therefore, it is not known whether induced resistance sensu Kloepper et al. (19) was, in fact, involved. Understanding the mechanisms by which a biological control agent reduces infection and subsequent development of pathogens is, however, important when evaluating an organism to be used in disease control. If induced resistance is involved in disease reductions, valuable information can be obtained on how the defense of the plant is expressed.

The natural basis for examining the mode of action of a biological control agent against a pathogen is to compare the infection biology of a pathogen with and without prior application of the control agent (i.e., only direct observations of the pathogen can determine at which steps its growth is inhibited or arrested and whether the expression of resistance mechanisms is enhanced by the biological control agent). In addition, histochemical and molecular methods can provide information about biochemical aspects of biological control processes.

The current study aims at investigating whether induced resistance is responsible for inhibiting $D$. teres (challenger) in barley after inocu-

Corresponding author: H. J. L. Jørgensen; E-mail address: hjo@kvl.dk

Publication no. P-1998-0514-01R

(C) 1998 The American Phytopathological Society lation with B. maydis and S. nodorum (inducers). This was done by quantitative histological examination of the primary infection stages of $D$. teres, by qualitative studies of the later development of this fungus, and by studies of the expression of defense response genes in the host after inducer inoculation with B. maydis and S. nodorum.

\section{MATERIALS AND METHODS}

Quantitative examination of the primary infection processes of $\boldsymbol{D}$. teres. Plants and experimental design. The spring barley (Hordeum vulgare) cv. Lenka was grown in the soil mix "Weibulls Enhetsjord" in a growth chamber as earlier described (14). When the first leaf was fully emerged and the second was expanding, 11 days after sowing, the first developed leaf of each of five plants per pot were fixed in a horizontal position on bent plastic plates, abaxial side upwards, using unbleached cotton strings (15).

The experiment comprised three pretreatments $(24 \mathrm{~h}$ before inoculation with $D$. teres): a conidial suspension of $B$. maydis, a conidial suspension of $S$. nodorum, or glass-distilled water alone (control). Sampling of leaves was carried out 3, 12, and $24 \mathrm{~h}$ after inoculation with $D$. teres. At each sampling time, a pretreatment was represented by two pots. All pots at a sampling time were placed according to a Latin square pattern in a tray.

Inoculum and inoculation. Inoculum of B. maydis (isolate $\mathrm{CP}$ 2050), S. nodorum (isolate CP 2052), and D. teres f. maculata (isolate CP 2051) were produced as described earlier (14). Inoculum of all organisms was harvested in glass-distilled water. For $B$. maydis and $S$. nodorum, 14-day-old cultures were used and the inoculum concentration adjusted to 20,000 and 2,000,000 conidia per ml, respectively, as described previously (14). For D. teres, 7day-old cultures were used and the inoculum concentration adjusted to 7,000 conidia per ml. This high concentration was used in order to make it easy to find the conidia. However, only conidia not in direct contact with others were studied.

Inoculum was sprayed onto the horizontally fixed leaves until runoff. Following application of either of the inducers or glass- 
distilled water, the test plants were incubated in plastic bags for $24 \mathrm{~h}$ in darkness to maintain a high relative humidity. About $20 \mathrm{~min}$ before inoculation with $D$. teres, the plastic bags were opened to let most of the droplets from the pretreatment dry up. After inoculation with $D$. teres, the plastic bags were resealed and incubated in darkness until sampling.

Sampling of leaves. Epidermal strips were made from the abaxial side of the leaves and mounted in lactoglycerol (lactic acid/glycerol/ water, 1:2:1). At each sampling time, the pretreatments were represented by 10 leaves (five leaves from each of the two pots). On each leaf, a number of developmental steps were recorded for 10 randomly chosen conidia of $D$. teres (a total of 100 conidia per pretreatment and per time). The strips were examined using normal light microscopy, differential interference-contrast microscopy (Normarski), and epifluorescence light microscopy (excitation maxima 365 and $450 \mathrm{~nm}$ ) (15). For each conidium, it was examined whether or not it germinated; for those germinated, the following parameters were recorded: number and length of germ tubes; whether the germ tubes branched; whether appressoria were produced; number of appressoria; whether penetrations took place from the appressoria, indicated by the development of infection vesicles (40) or formation of fluorescent epidermal cells (FEC); and whether intracellular hyphae developed from the infection vesicles. It was also recorded whether fluorescent papillae (FP) were formed as a response to penetration attempts and whether FEC occurred where $D$. teres actually did penetrate.

Statistical analysis. Some parameters measured are continuous variables (Tables 1 to 4 ): the average number and length of germ tubes and the average number of appressoria per conidium and per germ tube. These parameters were analyzed by analysis of variance or by Wilcoxon-Mann-Whitney's rank sum test (34). The other parameters in Tables 1 to 4 are discrete variables; it was recorded whether or not a certain event had taken place (e.g., whether or not a conidium had germinated). Therefore, these results were analyzed by logistic regression (corrected for overdispersion when present) (6) or by Fisher's exact test (8). For comparison of discrete variables (percentages), odds ratios (6) were calculated using the watertreated control plants as a reference. For example, the odds ratio for percent conidia with branched germ tubes is 3.04 (Table 1). This means that odds $(p /[1-p]$, in which $p$ is the probability of conidia having branched germ tubes), in B. maydis-treated plants are approximately three times higher than odds for control plants. For both continuous and discrete variables, hypotheses were rejected at $P \leq 0.05$. All data were analyzed by PC-SAS (release 6.11; SAS Institute, Cary, NC).

Qualitative examination of later developmental stages of $D$. teres. Two experiments were performed to examine later developmental stages of $D$. teres qualitatively. Barley plants 'Lenka' were grown and inoculated with inducers and challenger as before, except that the second developed leaf was inoculated adaxially, 14 to 15 days after sowing. In the first experiment, the concentration of $D$. teres used at the earliest sampling times $(8,24$, and $72 \mathrm{~h}$ after challenge inoculation) was 2,200 conidia per $\mathrm{ml}$. For the later sampling times $(120,168$, and $216 \mathrm{~h}$ after challenge inoculation), a concentration of 500 conidia per $\mathrm{ml}$ was used. In the second experiment, a concentration of 10,000 conidia of $D$. teres per $\mathrm{ml}$ was used for the early sampling times and a concentration of 600 conidia per $\mathrm{ml}$ for the late sampling times. Different inoculum concentrations were applied, because high inoculum densities were needed to study the initial phases of the interaction, whereas lower spore concentrations were needed for investigation of later stages (to avoid rapid leaf destruction).

At each sampling time, leaf pieces were prepared, sectioned, and stained with toluidine blue $\mathrm{O}, \mathrm{pH} 4.4$, for light microscopy, and two leaf segments ( $1 \mathrm{~cm}$ long) were prepared and examined as described earlier (15).

Expression of defense response genes following inducer inoculation alone. Three experiments were carried out in order to investigate the expression of defense response genes. Cultivation of plants and inoculation with either B. maydis, S. nodorum, or glass-distilled water took place as before, except that the first developed leaf of 7-day-old plants was used. No inoculation with $D$. teres was performed. For each of the three pretreatments, leaves were harvested from three pots $6,12,24,48$, and $96 \mathrm{~h}$ after inoculation. The leaves were immediately frozen in liquid nitrogen after harvest and stored at $-70^{\circ} \mathrm{C}$ until RNA extraction. The tissue samples were ground in liquid nitrogen. Total RNA was extracted as described previously $(7,11)$. Northern blots on Zetaprobe membranes (BioRad Laboratories, Richmond, CA) were prepared essentially according to Sambrook et al. (29). Probes of cDNA clones were prepared using the Megaprime DNA labeling systems (Amersham International, Amersham, United Kingdom). Hybridizations were performed according to Bryngelsson et al. (5), using six probes for transcripts representing the following proteins: PR-1a (probe: pHvPR-1a) (5); $\beta$-1,3-glucanase (PR-2; probe: pBH72-11) (T. Bryngelsson and P. L. Gregersen, unpub-

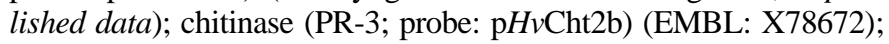
flavonoid $O$-methyltransferase (OMT; probe: pBH72-F1) (10); peroxidase (probe: pBH6-301) (37); and oxalate oxidase-like protein (HvOxOLP; probe: pBH6-903) (44). Final wash was performed at high stringency, $0.1 \times \mathrm{SSC}(1 \times \mathrm{SSC}$ is $0.15 \mathrm{M} \mathrm{NaCl}$ plus $0.015 \mathrm{M}$ sodium citrate), at $68^{\circ} \mathrm{C}$. The transcripts have been shown to be correlated with formation of papillae, hypersensitive responses (HR), and colony development in the interaction between barley and Erysiphe graminis f. sp. hordei (12). In this host-pathogen system, the transcripts for PR-2, PR-3, and peroxidase are expressed during papilla formation, HR, and colony development; the PR-1a and OMT transcripts are expressed during HR and colony development, whereas the $H v O x O L P$ transcript only is expressed during papilla formation $(5,10,12,37,44)$.

\section{RESULTS}

Primary infection processes of $D$. teres, $B$. maydis, and $S$. nodorum. $D$. teres conidia germinated with up to four, often branching, germ tubes. Most often a single appressorium formed terminally on a germ tube, but occasionally several appressoria were formed at positions along a germ tube or terminally on branches. Direct penetration into the lumen of an epidermal cell always took place from only one appressorium per germ tube and usually only from one germ tube per conidium. After successful penetration, the invading hypha developed a spherical infection vesicle within an epidermal cell. Subsequent fungal development resulted in the formation of one to several thick, short-celled intracellular hyphae radiating from the vesicle. Figure 1 shows a well-established infection of $D$. teres.

Two distinct host reactions occurred as a response to infections and infection attempts by $D$. teres. Fluorescence light microscopy revealed FP (Fig. 2, pa), where they appeared as bright circular structures, sometimes surrounded by a halo, in the outer epidermal cell wall just beneath appressoria attempting to penetrate. Growth of $D$. teres beyond the FP was rarely observed. The second type of host reaction observed consisted of FEC, seen as brightly fluorescent whole cells in the fluorescence light microscope (Fig. 3). FEC formed where $D$. teres had penetrated, but were not synchronized with any particular developmental step of this fungus. Thus, FEC sometimes were seen just after ingress of the penetration peg, but most often they were observed where $D$. teres had developed infection vesicles or intracellular hyphae. FP and FEC were not observed for all penetration attempts and infecting conidia, respectively (Tables 1 to 4 ).

B. maydis germinated with one to several germ tubes usually terminally from the conidia (Fig. 4). The germ tubes often branched, and appressoria were formed terminally on branches. Some germ tubes became very long before forming appressoria and attempting to penetrate, while other germ tubes quickly formed appressoria terminally but resumed growth and produced new appres- 
soria later. In this way, the fungus could develop profusely on the surface of the leaves. A part of the penetration attempts resulted in the formation of FP with halos in the leaf epidermis (Fig. 4), the appressoria sometimes strongly fluorescing themselves. Another part of the attempted penetrations by $B$. maydis resulted in the formation of FEC (Fig. 4). Growth of B. maydis through the FP or beyond the FEC was not observed. However, in some cases, $B$. maydis apparently did succeed in penetrating into the epidermal cells. Subsequently, small necroses developed in the barley tissue. The necroses, comprising several epidermal cells together with the underlying mesophyll cells, were seen with the naked eye as early as $24 \mathrm{~h}$ after inoculation as minute brown spots. The tissues around and in the necrotic lesions often attained green to turquoise colors when stained with toluidine blue $\mathrm{O}$, indicating accumulation of polyphenolic substances. Hyphal growth stopped shortly after penetration, so that only a very few short hyphae were formed intracellularly in the necrotic leaf tissue.

$S$. nodorum also germinated with one to several, occasionally branching, germ tubes that could grow for long distances across the leaf surface (Fig. 2). Penetration attempts took place from germ tubes without discernable appressoria and resulted in the formation of FP with halos in the host cell walls (Fig. 2). No growth of the fungus was observed beyond the FP, and FEC was not observed. However, occasionally, a few small and nonexpanding necroses barely visible to the naked eye developed in the leaf 3 to 5 days after inoculation with $S$. nodorum.

TABLE 1. Observed incidence of various developmental steps in the infection course of Drechslera teres in barley leaves pretreated with either water (control) or Bipolaris maydis from maize calculated per germinated conidium ${ }^{\mathrm{a}}$

\begin{tabular}{|c|c|c|c|c|c|c|c|}
\hline \multirow[b]{3}{*}{ D. teres infection process } & \multicolumn{6}{|c|}{ Time after inoculation with $D$. teres } & \multirow[b]{3}{*}{ Odds ratio $^{b}$} \\
\hline & \multicolumn{2}{|c|}{$3 \mathrm{~h}$} & \multicolumn{2}{|c|}{$12 \mathrm{~h}$} & \multicolumn{2}{|c|}{$24 \mathrm{~h}$} & \\
\hline & Control & B. maydis & Control & B. maydis & Control & B. maydis & \\
\hline Percent conidia germinated & 85.0 & 87.0 & 98.0 & 99.0 & 98.0 & 99.0 & $1.31^{\mathrm{NS}}$ \\
\hline Percent conidia with branched germ tubes & 1.2 & 1.1 & 24.5 & 45.5 & 27.6 & 58.6 & $3.04^{* * *}$ \\
\hline Percent conidia forming appressoria & 9.4 & 1.1 & 71.4 & 61.6 & 73.5 & 60.6 & $0.54^{* *}$ \\
\hline Percent conidia causing fluorescent papillae & $\ldots \mathrm{c}$ & $\ldots{ }^{c}$ & 33.7 & 34.3 & 21.4 & 37.4 & $1.47^{\mathrm{NS}}$ \\
\hline Percent conidia causing penetrations ${ }^{d}$ & $\ldots{ }^{c}$ & $\ldots{ }^{\mathrm{c}}$ & 27.6 & 11.1 & 35.7 & 10.1 & $0.26^{* * *}$ \\
\hline Percent conidia forming intracellular hyphae & $\ldots{ }^{c}$ & $\ldots{ }^{c}$ & 18.4 & 10.1 & 31.6 & 3.0 & $0.50^{\mathrm{NS}}, 0.07^{* * *} \mathrm{e}$ \\
\hline Percent conidia causing fluorescent epidermal cells & $\ldots^{c}$ & $\ldots^{\mathrm{c}}$ & 27.6 & 8.1 & 30.6 & 7.1 & $0.20^{* * *}$ \\
\hline Average number of germ tubes per conidium & 1.3 & 1.5 & 1.5 & 1.8 & 1.4 & 1.6 & ${ }^{\mathrm{f}}{ }^{\mathrm{n}}$ \\
\hline Average length of germ tubes per conidium $(\mu \mathrm{m})$ & 30.6 & 60.1 & 110.2 & 184.3 & 116.6 & 214.2 & $\ldots g$ \\
\hline Average number of appressoria per conidium & 0.1 & 0.01 & 0.8 & 0.8 & 0.8 & 1.2 & $\ldots{ }^{h}$ \\
\hline
\end{tabular}

a Values given are percentages (discrete data) and averages (continuous data).

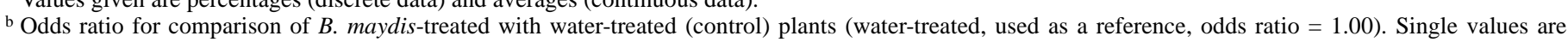
pooled over time by use of an additive logistic regression model. The number of asterisks indicates the degree of significance. NS $=$ nonsignificant difference, *** = significant at $P \leq 0.001$, ** $=$ significant at $P \leq 0.01$, and $*=$ significant at $P \leq 0.05$

c After $3 \mathrm{~h}, D$. teres had not developed farther than to form appressoria.

d Penetrations were indicated by formation of infection vesicles or fluorescent epidermal cells.

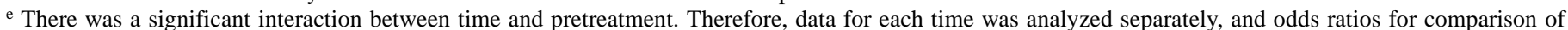
water-treated and B. maydis-treated plants were calculated for 12 and $24 \mathrm{~h}$, respectively.

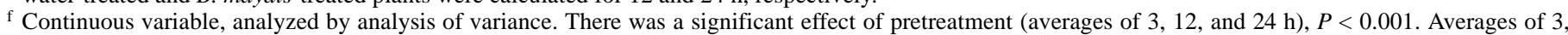
12 , and $24 \mathrm{~h}$ were 1.4 for water-treated and 1.7 for $B$. maydis-treated plants, $\mathrm{LSD}_{95}=0.1$.

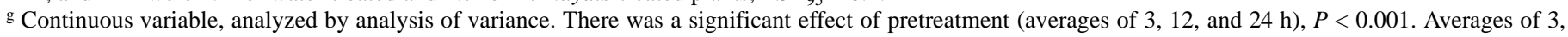
12 , and $24 \mathrm{~h}$ were 85.8 for water-treated and 152.9 for B. maydis-treated plants, $\mathrm{LSD}_{95}=22.2$.

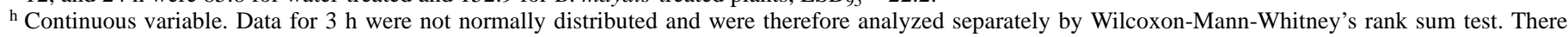
was no significant effect of pretreatment. Data for 12 and $24 \mathrm{~h}$ were normally distributed and were therefore analyzed together by analysis of variance. There was no significant effect of pretreatment here either (averages of 12 and $24 \mathrm{~h}$ ).

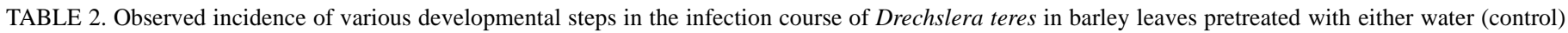
or Bipolaris maydis from maize calculated on the basis of the preceding developmental step or relative to the total number of a given structure

\begin{tabular}{|c|c|c|c|c|c|c|c|}
\hline \multirow[b]{3}{*}{ D. teres infection process } & \multicolumn{6}{|c|}{ Time after inoculation with $D$. teres } & \multirow[b]{3}{*}{ Odds ratio ${ }^{\mathrm{b}}$} \\
\hline & \multicolumn{2}{|c|}{$3 \mathrm{~h}$} & \multicolumn{2}{|c|}{$12 \mathrm{~h}$} & \multicolumn{2}{|c|}{$24 \mathrm{~h}$} & \\
\hline & Control & B. maydis & Control & B. maydis & Control & B. maydis & \\
\hline Percent conidia germinated & 85.0 & 87.0 & 98.0 & 99.0 & 98.0 & 99.0 & $1.31^{\mathrm{NS}}$ \\
\hline Percent branched germ tubes (of total formed) & 0.9 & 0.8 & 16.7 & 31.9 & 21.9 & 43.6 & $2.51^{* * * *}$ \\
\hline Percent germ tubes forming appressoria & 7.1 & 0.8 & 51.4 & 36.8 & 53.3 & 42.3 & $0.56^{* * * *}$ \\
\hline Percent appressoria causing fluorescent papillae & $\ldots{ }^{c}$ & $\ldots{ }^{c}$ & 44.2 & 53.3 & 32.9 & 62.1 & $2.28^{* *}$ \\
\hline Percent fluorescent papillae penetrated ${ }^{\mathrm{d}}$ & $\ldots{ }^{c}$ & $\ldots{ }^{c}$ & 17.6 & 7.5 & 7.4 & 8.3 & $0.62^{\mathrm{NS}}$ \\
\hline Percent appressoria causing penetrations ${ }^{\mathrm{d}}$ & $\ldots{ }^{c}$ & $\ldots{ }^{\mathrm{c}}$ & 35.1 & 14.7 & 42.7 & 9.5 & $0.20^{* * * *}$ \\
\hline Percent infection vesicles forming intracellular hyphae & $\ldots{ }^{c}$ & $\ldots{ }^{c}$ & 94.7 & 90.9 & 91.2 & 60.0 & $0.23^{\mathrm{NS}}$ \\
\hline Percent appressoria causing fluorescent epidermal cells & $\ldots^{\mathrm{c}}$ & $\ldots^{\mathrm{c}}$ & 35.1 & 10.7 & 36.6 & 6.9 & $0.16^{* * * *}$ \\
\hline Average length of germ tubes $(\mu \mathrm{m})$ & 22.7 & 39.8 & 75.6 & 98.3 & 82.8 & 130.1 & $\ldots e^{e}$ \\
\hline Average number of appressoria per germ tube & 0.1 & 0.01 & 0.5 & 0.4 & 0.6 & 0.7 & $\mathrm{f}^{\mathrm{f}}$ \\
\hline
\end{tabular}

a Values given are percentages (discrete data) and averages (continuous data).

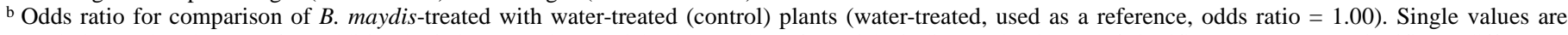
pooled over time by use of an additive logistic regression model. The number of asterisks indicates the degree of significance. NS $=$ nonsignificant difference, $* * *=$ significant at $P \leq 0.001, * *=$ significant at $P \leq 0.01$, and $*=$ significant at $P \leq 0.05$.

c After $3 \mathrm{~h}, D$. teres had not developed farther than to form appressoria.

d Penetrations were indicated by formation of infection vesicles or fluorescent epidermal cells.

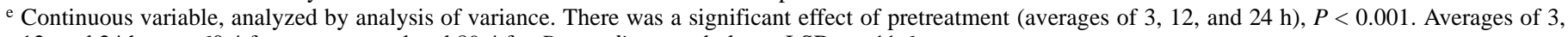

12 , and $24 \mathrm{~h}$ were 60.4 for water-treated and 89.4 for B. maydis-treated plants, $\mathrm{LSD}_{95}=11.6$.

${ }^{\mathrm{f}}$ Continuous variable, analyzed by analysis of variance. There was no significant effect of pretreatment (averages of 3 , 12 , and $24 \mathrm{~h}$ ). 
Inhibition of $\boldsymbol{D}$. teres following inducer inoculation. Quantitative examination of the primary infection processes of $\mathrm{D}$. teres. Tables 1 and 2 present data for $B$. maydis used as inducer, and Tables 3 and 4 present data for $S$. nodorum as inducer. In Tables 1 and 3, data for each stage of the infection process are presented relative to the number of germinated conidia. In Tables 2 and 4, data for the single steps are presented relative to the preceding steps in the infection process of $D$. teres (e.g., percent appressoria giving penetrations and percent infection vesicles giving intracellular hyphae) or relative to the total number of a given structure (e.g., percent branching germ tubes out of total number of germ tubes). This was done in order to determine whether the pathogen was inhibited at any specific step of the infection process (Tables 2 and 4 ) or if the development of $D$. teres was merely reduced as a consequence of the cumulative inhibition of all previous developmental steps (Tables 1 and 3). Figure 5 shows all combinations of observed events in the infection process of $D$. teres and their frequencies after preinoculation with either of the inducers or water. The percentages presented in the figure are calculated on the basis of 100 conidia, as in Tables 1 and 3 .

B. maydis application did not significantly affect germination of $D$. teres conidia, whereas average number, average length, and branch-

TABLE 3. Observed incidence of various developmental steps in the infection course of Drechslera teres in barley leaves pretreated with either water (control) or Septoria nodorum from wheat calculated per germinated conidium ${ }^{\mathrm{a}}$

\begin{tabular}{|c|c|c|c|c|c|c|c|}
\hline \multirow[b]{3}{*}{ D. teres infection process } & \multicolumn{6}{|c|}{ Time after inoculation with $D$. teres } & \multirow[b]{3}{*}{ Odds ratio ${ }^{b}$} \\
\hline & \multicolumn{2}{|c|}{$3 \mathrm{~h}$} & \multicolumn{2}{|c|}{$12 \mathrm{~h}$} & \multicolumn{2}{|c|}{$24 \mathrm{~h}$} & \\
\hline & Control & S. nodorum & Control & S. nodorum & Control & S. nodorum & \\
\hline Percent conidia germinated & 85.0 & 78.0 & 98.0 & 91.0 & 98.0 & 97.0 & $0.51^{*}$ \\
\hline Percent conidia forming appressoria & 9.4 & 5.1 & 71.4 & 38.5 & 73.5 & 52.6 & $0.33^{* * *}$ \\
\hline Percent conidia causing fluorescent papillae & $\ldots^{c}$ & $\ldots^{\mathrm{c}}$ & 33.7 & 12.1 & 21.4 & 30.9 & $0.27^{* * *}, 1.64^{\mathrm{NS}^{\mathrm{d}}}$ \\
\hline Percent conidia causing penetrations ${ }^{\mathrm{e}}$ & $\ldots^{\mathrm{c}}$ & $\ldots^{c}$ & 27.6 & 6.6 & 35.7 & 9.3 & $0.18^{* * *}$ \\
\hline Average number of germ tubes per conidium & 1.3 & 1.3 & 1.5 & 1.4 & 1.4 & 1.3 & $\ldots{ }^{\mathrm{f}}$ \\
\hline Average length of germ tubes per conidium $(\mu \mathrm{m})$ & 30.6 & 31.5 & 110.2 & 75.5 & 116.6 & 126.3 & $\ldots \mathrm{f}$ \\
\hline Average number of appressoria per conidium & 0.1 & 0.1 & 0.8 & 0.4 & 0.8 & 0.6 & $\ldots \mathrm{g}$ \\
\hline
\end{tabular}

${ }^{a}$ Values given are percentages (discrete data) and averages (continuous data).

b Odds ratio for comparison of $S$. nodorum-treated with water-treated (control) plants (water-treated, used as a reference, odds ratio $=1.00$ ). Single values are pooled over time by use of an additive logistic regression model. The number of asterisks indicates the degree of significance. NS $=$ nonsignificant difference, *** = significant at $P \leq 0.001$, ** $=$ significant at $P \leq 0.01$, and $*=$ significant at $P \leq 0.05$.

${ }^{c}$ After $3 \mathrm{~h}, D$. teres had not developed farther than to form appressoria.

$\mathrm{d}$ There was a significant interaction between time and pretreatment. Therefore, data for each time was analyzed separately and odds ratios for comparison of water-treated and $S$. nodorum-treated plants were calculated for 12 and $24 \mathrm{~h}$, respectively.

e Penetrations were indicated by formation of infection vesicles or fluorescent epidermal cells.

${ }^{\mathrm{f}}$ Continuous variable, analyzed by analysis of variance. There was no significant effect of pretreatment (averages of 3,12 , and $24 \mathrm{~h}$ ).

$\mathrm{g}$ Continuous variable, analyzed by analysis of variance. There was a significant effect of pretreatment (averages of 3,12 , and $24 \mathrm{~h}$ ), $P<0.001$. Averages of 3 , 12 , and $24 \mathrm{~h}$ were 0.6 for water-treated and 0.4 for $S$. nodorum-treated plants, $\mathrm{LSD}_{95}=0.1$.

TABLE 4. Observed incidence of various developmental steps in the infection course of Drechslera teres in barley leaves pretreated with either water (control) or Septoria nodorum from wheat, calculated on the basis of the preceding developmental step or relative to the total number of a given structure ${ }^{\mathrm{a}}$

\begin{tabular}{|c|c|c|c|c|c|c|c|}
\hline \multirow[b]{3}{*}{ D. teres infection process } & \multicolumn{6}{|c|}{ Time after inoculation with $D$. teres } & \multirow[b]{3}{*}{ Odds ratio ${ }^{\mathrm{b}}$} \\
\hline & \multicolumn{2}{|c|}{$3 \mathrm{~h}$} & \multicolumn{2}{|c|}{$12 \mathrm{~h}$} & \multicolumn{2}{|c|}{$24 \mathrm{~h}$} & \\
\hline & Control & S. nodorum & Control & S. nodorum & Control & S. nodorum & \\
\hline Percent conidia germinated & 85.0 & 78.0 & 98.0 & 91.0 & 98.0 & 97.0 & $0.51^{*}$ \\
\hline Percent branched germ tubes (of total formed) & 0.9 & 2.9 & 16.7 & 9.2 & 21.9 & 19.5 & $0.75^{\mathrm{NS}}$ \\
\hline Percent germ tubes forming appressoria & 7.1 & 3.9 & 51.4 & 29.2 & 53.3 & 40.6 & $0.49^{* * * *}$ \\
\hline Percent appressoria causing fluorescent papillae & $\ldots{ }^{c}$ & $\ldots{ }^{\mathrm{c}}$ & 44.2 & 28.2 & 32.9 & 59.0 & $0.50^{\mathrm{NS}}, 2.93^{* \mathrm{~d}}$ \\
\hline Percent fluorescent papillae penetrated $\mathrm{e}^{\mathrm{e}}$ & $\ldots^{\mathrm{c}}$ & $\ldots{ }^{\mathrm{c}}$ & 17.6 & 0.0 & 7.4 & 2.8 & NS, $\mathrm{NS}^{\mathrm{f}}$ \\
\hline Percent appressoria causing penetrations $\mathrm{e}^{\mathrm{e}}$ & $\ldots^{\mathrm{c}}$ & $\ldots^{\mathrm{c}}$ & 35.1 & 15.4 & 42.7 & 14.8 & $0.27^{* * * *}$ \\
\hline Percent infection vesicles forming intracellular hyphae & $\ldots^{\mathrm{c}}$ & $\ldots^{\mathrm{c}}$ & 94.7 & 100.0 & 91.2 & 100.0 & NS, $\mathrm{NS}^{\mathrm{f}}$ \\
\hline Percent appressoria causing fluorescent epidermal cells & $\ldots^{c}$ & $\ldots^{\mathrm{c}}$ & 35.1 & 15.4 & 36.6 & 13.1 & $0.29^{* * *}$ \\
\hline Average length of germ tubes $(\mu \mathrm{m})$ & 22.7 & 23.6 & 75.6 & 53.4 & 82.8 & 95.1 &..$^{g}$ \\
\hline Average number of appressoria per germ tube & 0.1 & 0.04 & 0.5 & 0.3 & 0.6 & 0.5 & $\ldots{ }^{h}$ \\
\hline
\end{tabular}

a Values given are percentages (discrete data) and averages (continuous data).

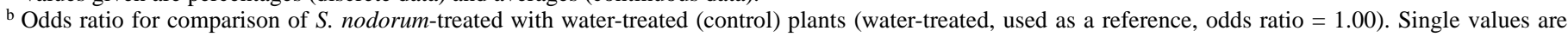
pooled over time by use of an additive logistic regression model. The number of asterisks indicates the degree of significance. NS $=$ nonsignificant difference, $* * *=$ significant at $P \leq 0.001, * *=$ significant at $P \leq 0.01$, and $*=$ significant at $P \leq 0.05$.

c After $3 \mathrm{~h}, D$. teres had not developed farther than to form appressoria.

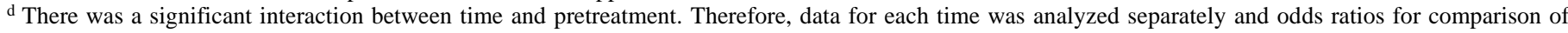
water-treated and $S$. nodorum-treated plants were calculated for 12 and $24 \mathrm{~h}$, respectively.

e Penetrations were indicated by formation of infection vesicles or fluorescent epidermal cells.

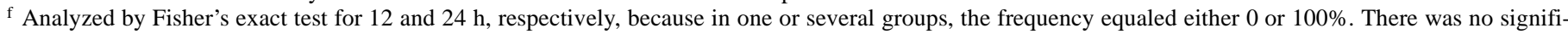
cant difference between water-treated and $S$. nodorum-treated plants for either 12 or $24 \mathrm{~h}$.

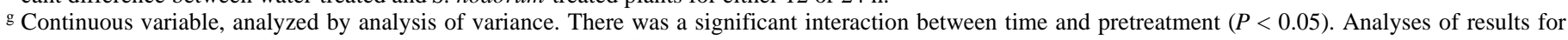
each time showed that, for $12 \mathrm{~h}$, germ tube length was significantly shorter for $S$. nodorum-treated than for water-treated plants $(P<0.05)$, LSD $95=18.0$, whereas for 3 and $24 \mathrm{~h}$, there were no significant differences.

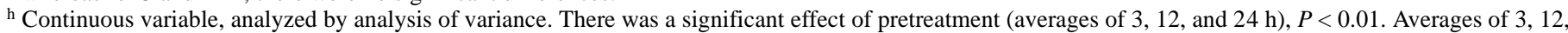
and $24 \mathrm{~h}$ were 0.4 for water-treated and 0.3 for $S$. nodorum-treated plants, $\mathrm{LSD}_{95}=0.1$. 
ing of germ tubes were significantly increased by $B$. maydis (Tables 1 and 2). On the other hand, B. maydis application significantly reduced appressorium formation (Tables 1 and 2). Thus, after $24 \mathrm{~h}$, 61 and $42 \%$ of the conidia and germ tubes, respectively, formed

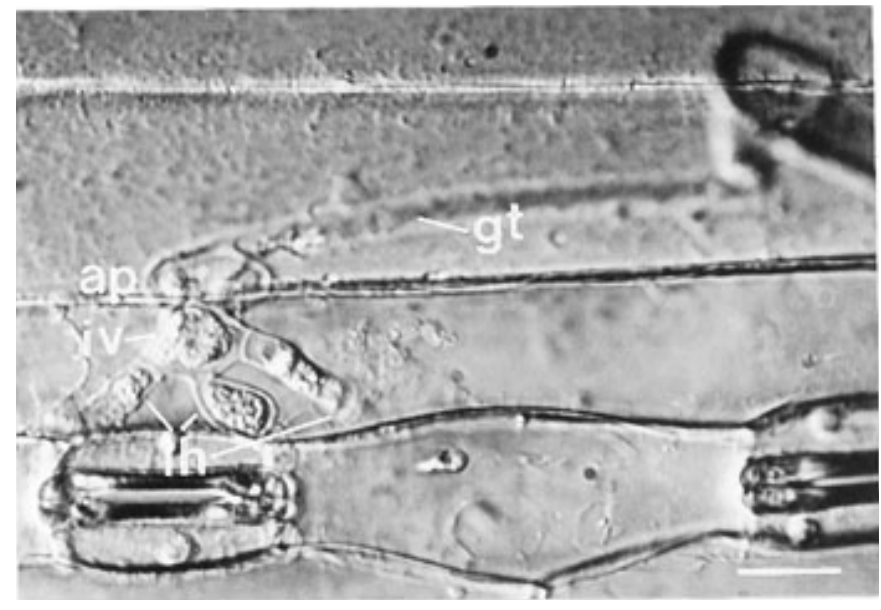

Fig. 1. Normarski micrograph showing a well-established infection of Drechslera teres in an epidermal strip made from a barley leaf receiving no pretreatment, $24 \mathrm{~h}$ after inoculation with the pathogen. From an appressorium (ap) at the tip of a germ tube (gt), the fungus penetrates the outer epidermal cell wall and produces an infection vesicle (iv) from which intracellular hyphae (ih) start to develop. Bar $=20 \mu \mathrm{m}$.
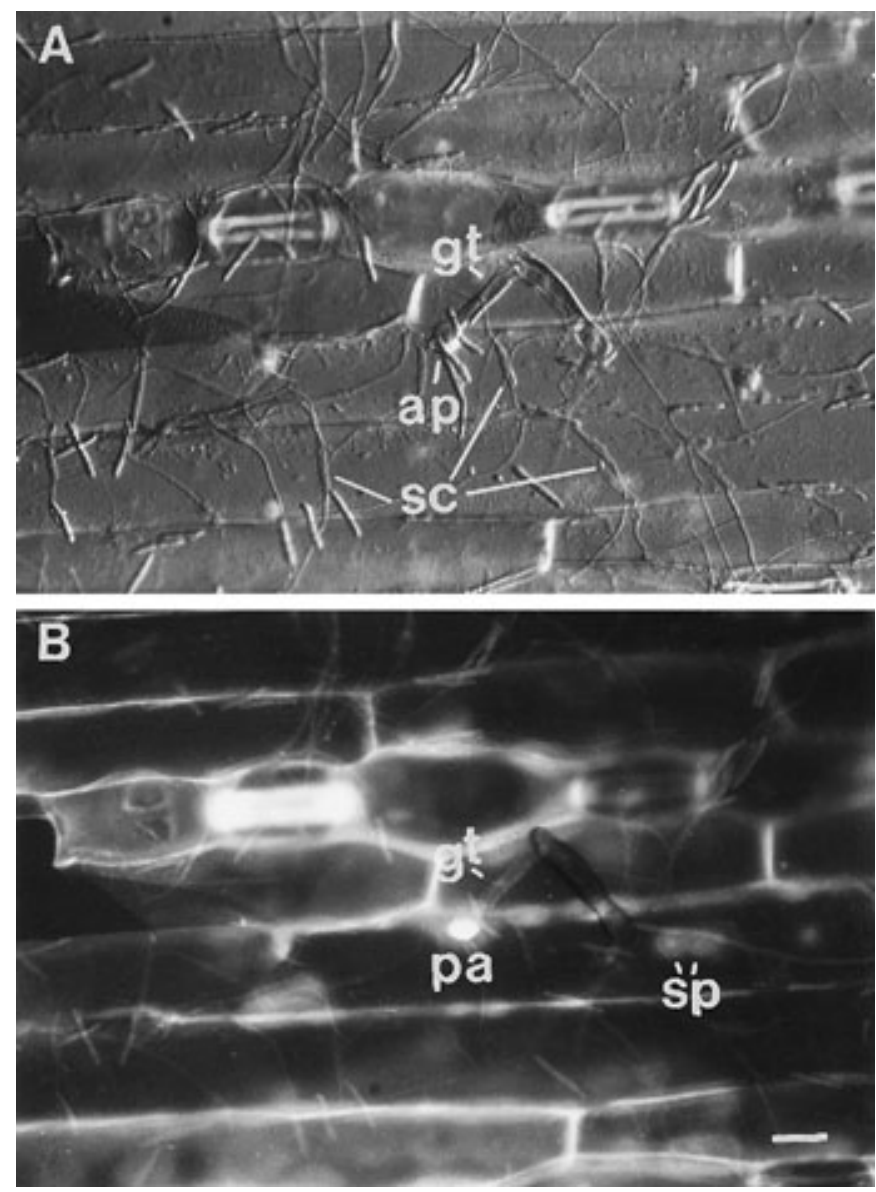

Fig. 2. Epidermal strip of a barley leaf pretreated with Septoria nodorum $24 \mathrm{~h}$ before inoculation with Drechslera teres. A, Normarski micrograph; and B, fluorescence light micrograph of the same site. Micrographs were made $24 \mathrm{~h}$ after inoculation with $D$. teres. A conidium of $D$. teres has germinated with one germ tube (gt). Subjacent to the appressorium (ap), a papilla (pa) with a halo is formed. Scattered over the leaf are several $S$. nodorum conidia (sc) that have germinated with long, slender germ tubes. Occasionally, S. nodorum infection attempts result in papilla formation (sp). Bar $=20 \mu \mathrm{m}$. appressoria in B. maydis-treated leaves, whereas 74 and $53 \%$, respectively, did so in the controls.

Penetration of $D$. teres (indicated by formation of infection vesicles or FEC) was strongly inhibited by B. maydis (Tables 1 and 2); after 24 h, only 10 and $10 \%$ of the $D$. teres conidia and appressoria, respectively, on the B. maydis-treated leaves penetrated, compared with

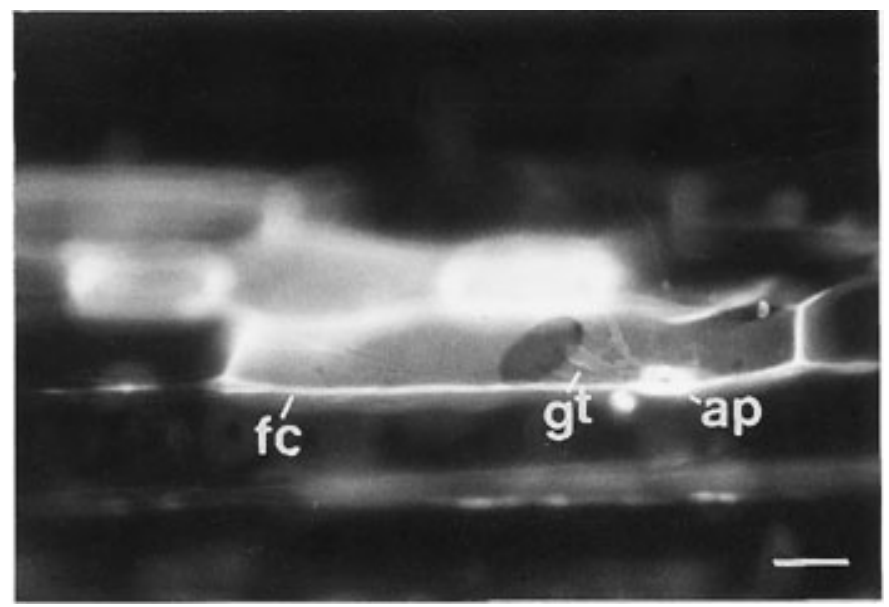

Fig. 3. Fluorescence light micrograph of epidermal strip made $24 \mathrm{~h}$ after inoculation with Drechslera teres from a barley leaf pretreated with Septoria nodorum. A conidium of $D$. teres has germinated and produced an appressorium (ap) at the tip of a germ tube (gt), and the infection hypha has invaded a cell, resulting in whole-cell fluorescence (fc) of this cell. Underlying the appressorium, a fluorescing papilla is seen. Bar $=20 \mu \mathrm{m}$.
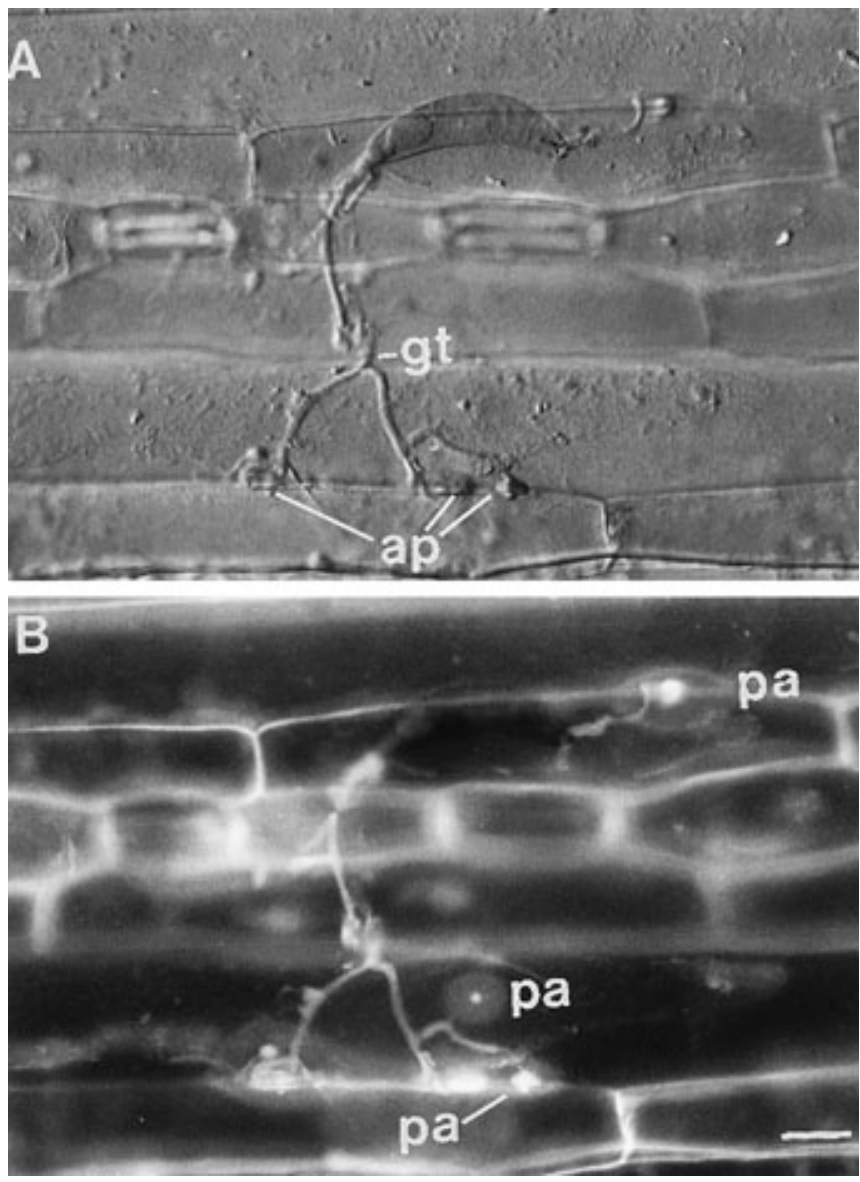

Fig. 4. Barley epidermal strip pretreated with Bipolaris maydis $24 \mathrm{~h}$ before inoculation with Drechslera teres. A, Normarski micrograph; and $\mathbf{B}$, fluorescence light micrograph of the same site. Micrographs were made $24 \mathrm{~h}$ after inoculation with $D$. teres. A conidium of $B$. maydis has produced a branched germ tube (gt) attempting to penetrate from several appressoria (ap). Papillae (pa) with halos are formed as a response to infection attempts. Bar $=20 \mu \mathrm{m}$. 
36 and $43 \%$, respectively, in the controls. Also, significantly fewer conidia of $D$. teres produced intracellular hyphae from the infection vesicles after B. maydis application (32 and 3\% after $24 \mathrm{~h}$ for controls and B. maydis-treated leaves, respectively) (Table 1). The ability of infection vesicles to form intracellular hyphae (Table 2) was also reduced by $B$. maydis application, although not significantly.

$B$. maydis significantly increased the proportion of $D$. teres appressoria giving FP (Table 2). The proportion of conidia causing FP was also higher for B. maydis-treated plants; however, not significantly (Table 1). The percentage of FP penetrated was not significantly different between inducer-treated and control plants (Table
2). D. teres caused FEC significantly more often in the controls than after B. maydis treatment (Tables 1 and 2).

$S$. nodorum application significantly reduced the germination of D. teres (Tables 3 and 4), whereas average number, average length, and branching of germ tubes per conidium (Table 3), as well as the percentage of branched germ tubes (Table 4), were not significantly affected. Appressorium formation of $D$. teres was significantly inhibited by $S$. nodorum (Tables 3 and 4). Hence, the percentage of conidia and germ tubes forming appressoria were reduced from 74 and $53 \%$, respectively, in the controls to 53 and $41 \%$, respectively, in the $S$. nodorum-treated leaves.

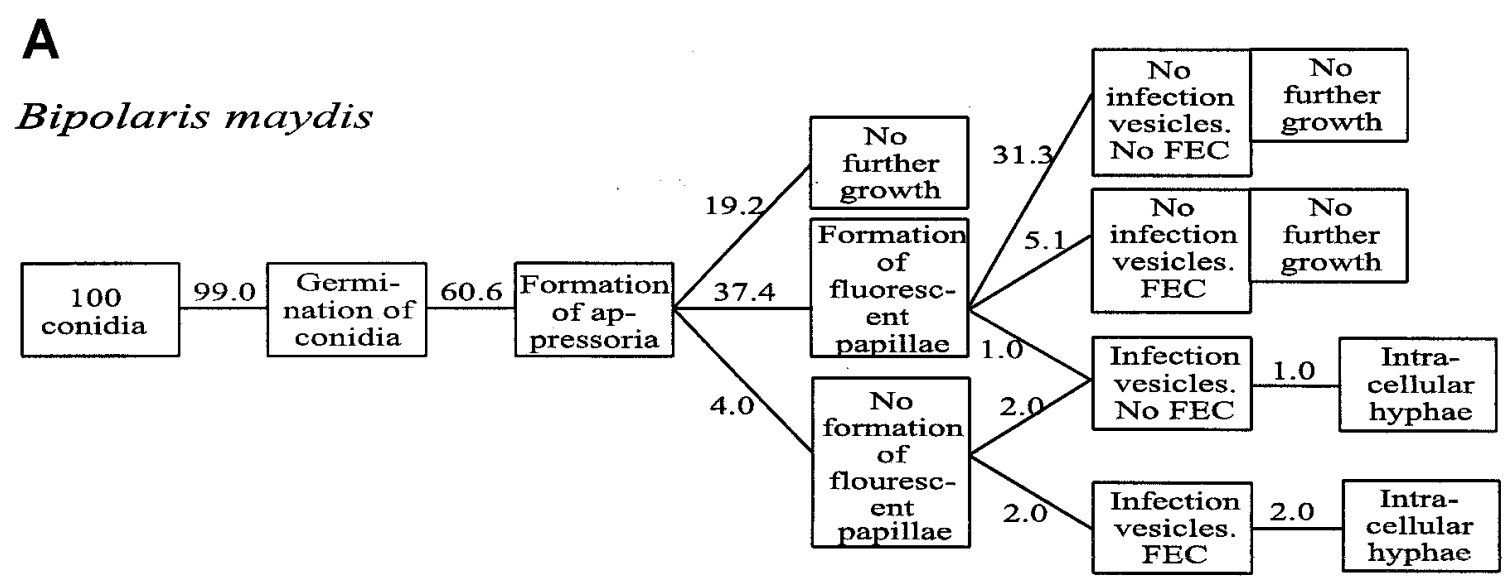

B
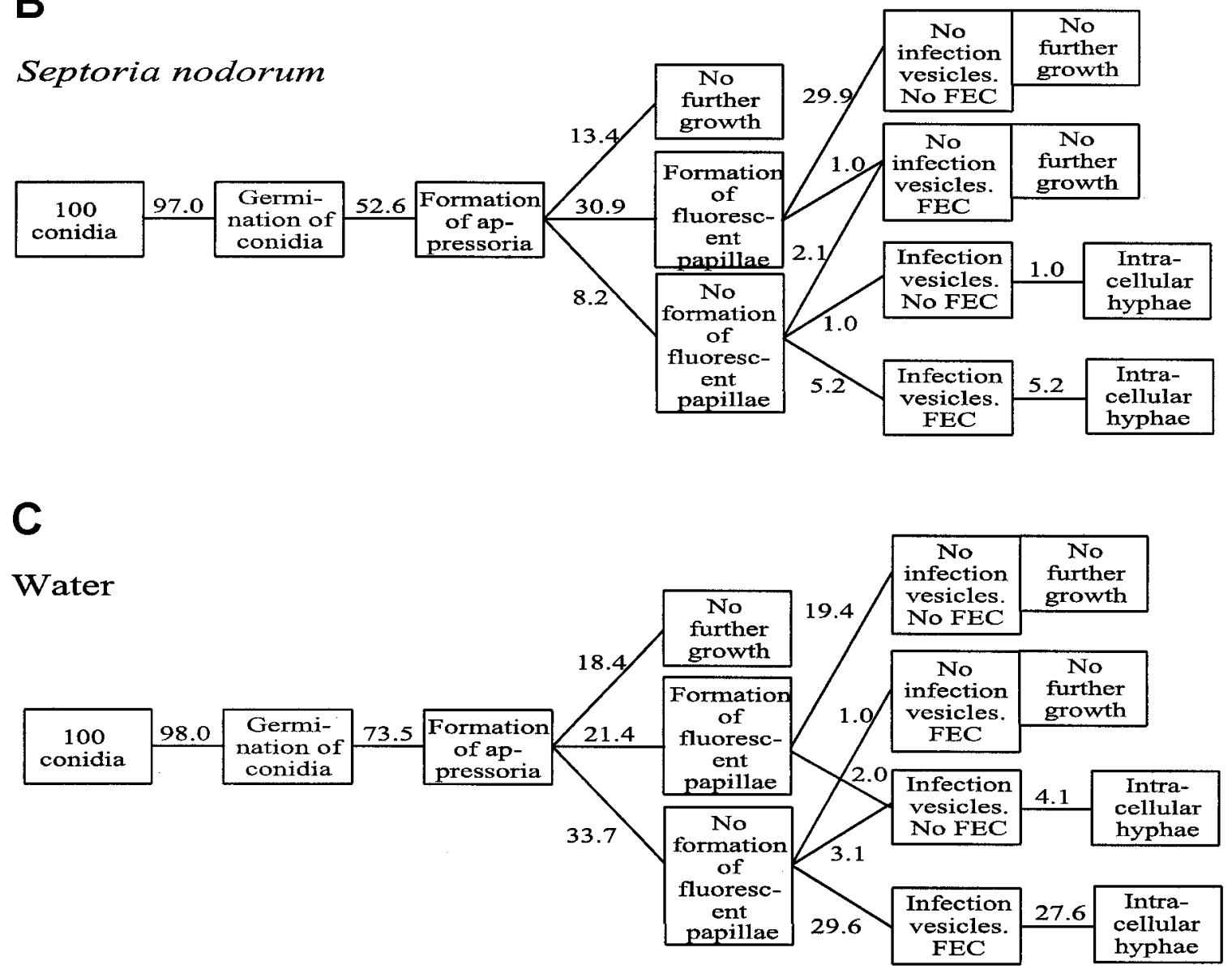

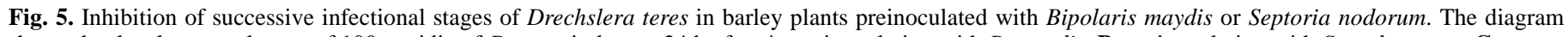

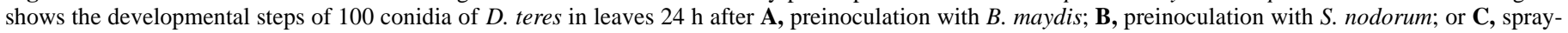
ing with water (control). $\mathrm{FEC}=$ fluorescent epidermal cells. 
Penetration of $D$. teres was significantly inhibited by $S$. nodorum application. Thus, 36 and $43 \%$ of conidia and appressoria, respectively, caused penetration in the controls, whereas this was reduced to 9 and 5\%, respectively, after S. nodorum treatment (Tables 3 and 4). Likewise, significantly fewer conidia developed intracellular hyphae in the $S$. nodorum-treated leaves than in the controls (Table 3). This reflects the low penetration frequency, since the ability of infection vesicles, once established, to form intracellular hyphae was not significantly different (Table 4).

Significantly fewer conidia caused formation of FP in the $S$. nodorum-treated leaves than in the control plants after $12 \mathrm{~h}$. This situation changed at $24 \mathrm{~h}$, in which more $D$. teres conidia caused FP to be formed in the $S$. nodorum-treated leaves, although this difference was not significant (Table 3). On the other hand, the ability of individual appressoria to cause formation of FP (Table 4) was not significantly different between pretreatments after $12 \mathrm{~h}$, whereas a significantly higher proportion of appressoria caused FP to form in the $S$. nodorum-treated leaves than in the controls after $24 \mathrm{~h}$. There was, however, no significant difference between inducer-treated and control plants regarding the percentage of FP penetrated (Table 4). The proportion of conidia (Table 3) and ap-

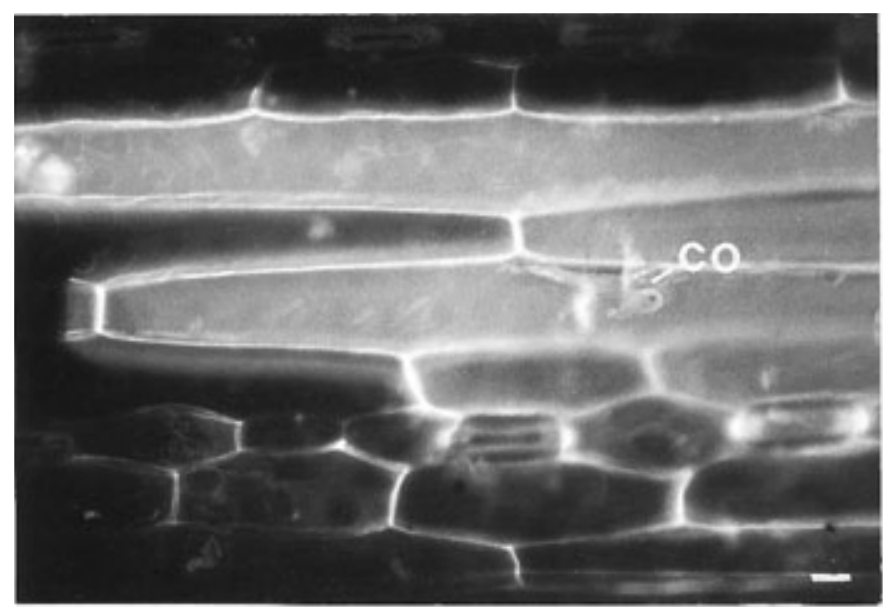

Fig. 6. Fluorescence light micrograph of barley epidermal strip made $48 \mathrm{~h}$ after inoculation with Drechslera teres from a leaf pretreated with Bipolaris maydis. A conidium of $D$. teres (co) has invaded a host cell, resulting in whole-cell fluorescence of several cells. This response is believed to constitute the first step in development of a multicellular hypersensitive response that later develops into a brown lesion (i.e., the macroscopic symptoms of infection). Bar $=20 \mu \mathrm{m}$.
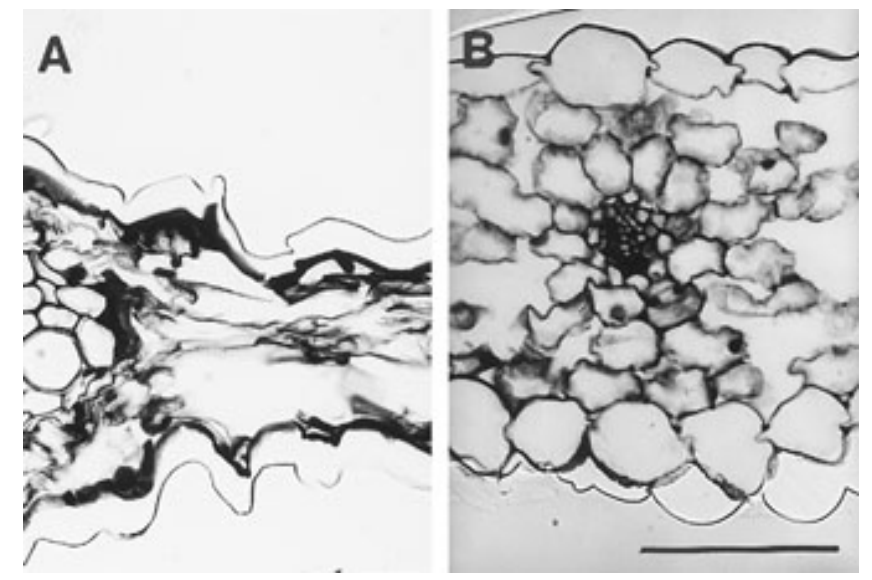

Fig. 7. Transverse sections of barley leaves 9 days after inoculation with Drechslera teres. A, Leaf receiving no pretreatment and $\mathbf{B}$, leaf pretreated with Bipolaris maydis $24 \mathrm{~h}$ before inoculation with $D$. teres. A, The tissues are completely degraded except for the vascular bundle. B, The tissues have retained their original structure and appear unaffected by inoculation with the pathogen. Bar $=100 \mu \mathrm{m}$. pressoria (Table 4) giving FEC was significantly lower in the $S$. nodorum-treated plants than in the controls.

Qualitative examination of the later developmental steps of $\mathrm{D}$. teres. B. maydis and S. nodorum did not develop further in the barley leaves than previously described. For $D$. teres in noninduced control leaves, brown lesions became apparent as macroscopic symptoms of infection 3 to 4 days after inoculation. The lesions enlarged during the next 3 to 5 days to attain their final sizes. Rather limited hyphal growth of $D$. teres was observed within the lesion areas, the hyphae often being thin, only sparsely stained, and with a grainy appearance after staining with toluidine blue O. Figure 6 shows an early stage of the development of such a lesion. However, when the fungus grew from the lesions into the surrounding tissue, the hyphal appearance changed. Numerous, rather thick hyphae, which stained deeply blue with toluidine blue $\mathrm{O}$, developed intercellularly. Most of these hyphae were seen in the mesophyll, with only a few spreading into the epidermis; none were observed in the vascular tissues. Progression of the hyphae was accompanied with extensive collapse and degradation of tissues (Fig. 7), especially in the initial brown lesions. Epidermis and mesophyll were severely affected, and in several vascular bundles, the cells were degraded as well. Commonly, the disintegrated leaf tissue around the progressing hyphae were stained green to turquoise, indicating the accumulation of polyphenolic substances, with the heaviest staining in and around the initial brown lesions. At the last sampling time (216 h after challenge inoculation), sporulation of D. teres had commenced on several places on the leaf surfaces between the brown lesions.

In leaves inducer-inoculated with either B. maydis or S. nodorum, brown necrotic spots also developed as a response to challenge inoculation with $D$. teres. However, these lesions remained smaller in size and fewer in number than on the control leaves. Hyphal growth of $D$. teres within the lesions was very limited, with only a few short, sparsely stained, thin hyphae. Spread of $D$. teres outside the brown necrotic spots was not observed for B. maydis and only to a very limited extent for $S$. nodorum as inducer. For the latter inducer, the hyphae outside the lesions were thick and heavily stained with toluidine blue $\mathrm{O}$, as in the control leaves. Mesophyll and epidermal tissues were degraded to a limited extent within and around the brown lesions (Fig. 7), whereas the vascular bundles were not affected. Green to turquoise staining with toluidine blue $\mathrm{O}$ was limited, concentrated in the degraded tissues. Sporulation of $D$. teres was not observed in any case.

Expression of defense response genes following inducer inoculation alone. Hybridizations to the transcripts for PR-1a, PR-2, PR-3, OMT, peroxidase, and $H \nu$ OxOLP all showed certain common characteristics, but clear differences between the transcripts were also observed (Fig. 8). All six transcripts had a maximum level of expression $24 \mathrm{~h}$ after inoculation with $B$. maydis. For $S$. nodorum, high expression of the six transcripts took place after $96 \mathrm{~h}$ and was preceded by a gradual increase. The transcript accumulation patterns for the three pathogenesis-related (PR) proteins, PR-1a, PR-2, and PR-3, were nearly identical for both inducers. The peroxidase transcript followed the same accumulation pattern, except that the induction by B. maydis was weaker. The 96-h peak caused by $S$. nodorum was similar in intensity to the PR-protein transcripts. The flavonoid OMT transcript had an accumulation pattern that was similar to the peroxidase transcript, the only major difference being an increased induction at $96 \mathrm{~h}$ after inoculation with $B$. maydis. The transcript for $H \nu \mathrm{OxOLP}$ accumulated only to a low level, particularly following inoculation with B. maydis.

\section{DISCUSSION}

Inducer inoculation of barley leaves with B. maydis or $S$. nodorum significantly inhibited several developmental steps of $D$. teres, resulting in reduced size and number of lesions as previ- 
ously described (14). The initial stages of the infection process for $D$. teres were studied quantitatively in order to determine whether the pathogen was inhibited before, during, or after penetration. To our knowledge, such quantitative data for the interaction between $D$. teres and barley have not been published before.

The current investigation confirms the general pattern of $D$. teres development previously described $(9,17,40)$. However, in contrast to observations by Van Caesele and Grumbles (40) but in agreement with Coyle and Cooke (9), we observed germination of conidia to take place rapidly and virtually synchronously. On the other hand, Coyle and Cooke (9) found that sporulation commenced 5 days after inoculation, whereas we found mature conidia only after 9 days. Only a small fraction of the $D$. teres conidia progressed to produce intracellular hyphae, even in the control plants. From quantitative studies of other plant-pathogen systems, it is also known that even in fully susceptible interactions only a fraction, quite often very small, of the spores capable of causing infection actually do progress to become well established in the host $(3,13,35,43)$.

Prepenetration growth of $D$. teres was affected differently by $B$. maydis and $S$. nodorum. $S$. nodorum reduced conidial germination and appressorium formation of $D$. teres, whereas $B$. maydis only reduced appressorium formation, but significantly increased most of the other examined prepenetration growth stages of $D$. teres. This inhibitory influence of the inducers suggests that a kind of antibiotic or competitive effect may play a certain role. Keeling and Banttari (16), studying the development of $D$. teres in resistant and susceptible barley cultivars, observed that neither spore germination nor number, length, or branching of germ tubes significantly differed between the cultivars. However, there are reports suggesting that the resistance of various grass species may indeed influence the prepenetration growth of pathogens as indicated from studies involving B. sorokiniana (25), Rhynchosporium secalis (22), and $S$. nodorum (4). Further investigations on the prepenetration inhibition of $D$. teres by $B$. maydis and $S$. nodorum are needed to examine whether antibiosis, competition, or both are, in fact, involved at this stage.

Preinoculation with either $B$. maydis or $S$. nodorum strongly reduced the number of $D$. teres conidia causing penetrations (formation of infection vesicles or FEC), but, in addition, fewer appressoria caused penetrations. Inhibition of penetration was not observed by Keeling and Banttari (16) for barley cultivars resistant to $D$. teres. Likewise, significantly fewer conidia of $D$. teres developed intracellular hyphae after inducer treatment, although the ability of the infection vesicles to form intracellular hyphae was not reduced. These results show that newly established infections of $D$. teres were unaffected by inducer application and that the considerable reduction in the number of spores forming intracellular hyphae was the result of a reduced number of conidia progressing to this developmental step.

As a response to penetration attempts by $D$. teres, FP were quite often formed. FP are a well-known primary resistance mechanism against penetration attempts by both pathogens and nonpathogens $(1,15,30,41,42)$. Formation of papillae as a response to infection attempts by $D$. teres has been described previously $(17,40)$. However, only Keon and Hargreaves (17) positively linked papilla formation to inhibition of penetration of the pathogen. Increased formation of FP was also found to be an important factor in induced resistance in barley against powdery mildew $(28,38)$. In our experiments, the increased frequency of FP may partly explain the observed inhibition of $D$. teres during its penetration in inducerinoculated leaves. Thus, the proportion of $D$. teres appressoria giving FP was significantly higher for $B$. maydis-treated than for control leaves. This was also observed after $24 \mathrm{~h}$ for $S$. nodorum as inducer. There was no significant difference between inducertreated and control plants regarding the percentage of FP penetrated for either inducer. This appears to indicate that an increased frequency and not increased efficiency of FP is responsible for the inhibition of $D$. teres. However, FP formation alone apparently cannot explain the increased inhibition of D. teres penetration. This was suggested by the observation that penetration of $D$. teres was inhibited by $S$. nodorum at both 12 and $24 \mathrm{~h}$, whereas formation of FP was only significantly increased (percent appressoria forming FP) after $24 \mathrm{~h}$. A possible explanation could be that a nonpapilla-based inhibition of penetration was involved, but we do not have any other data suggesting that such a mechanism is functioning in our experiments. Another, more likely, reason might be that not all papillae that effectively stopped $D$. teres penetration did, in fact, fluoresce; thus, they were not detected by fluorescence light microscopy. Such possible nonfluorescing papillae would camouflage the true extent of papillae formation. Nonfluorescing papillae, effective in stopping infection of E. graminis f. sp. hordei, was observed by Zeyen et al. (46) in mlo-resistant barley plants.

In the interaction between barley and E. graminis f. sp. hordei, FEC is a well-known phenomenon, and the autofluorescence has been taken as a manifestation of the HR $(21,24,43,45)$, which is known to restrict growth of the fungus some time after penetration $(1,18,21,43,45)$. FEC has apparently not been described as a response to infection by $D$. teres before. We observed FEC quite frequently where $D$. teres had developed after penetration, but more often in control leaves than in inducer-treated leaves. Therefore, formation of FEC is not correlated with inhibition of $D$. teres by inducer application and, hence, cannot explain the suppression of the pathogen in the current investigation. Sahashi and Shishiyama (28) apparently also found that FEC was not responsible for the increased suppression of E. graminis f. sp. hordei after induction of resistance in barley against this pathogen. In the current study, it should be stressed that neither the composition of the fluorescing

\section{Probe B. maydis S nodorum control}
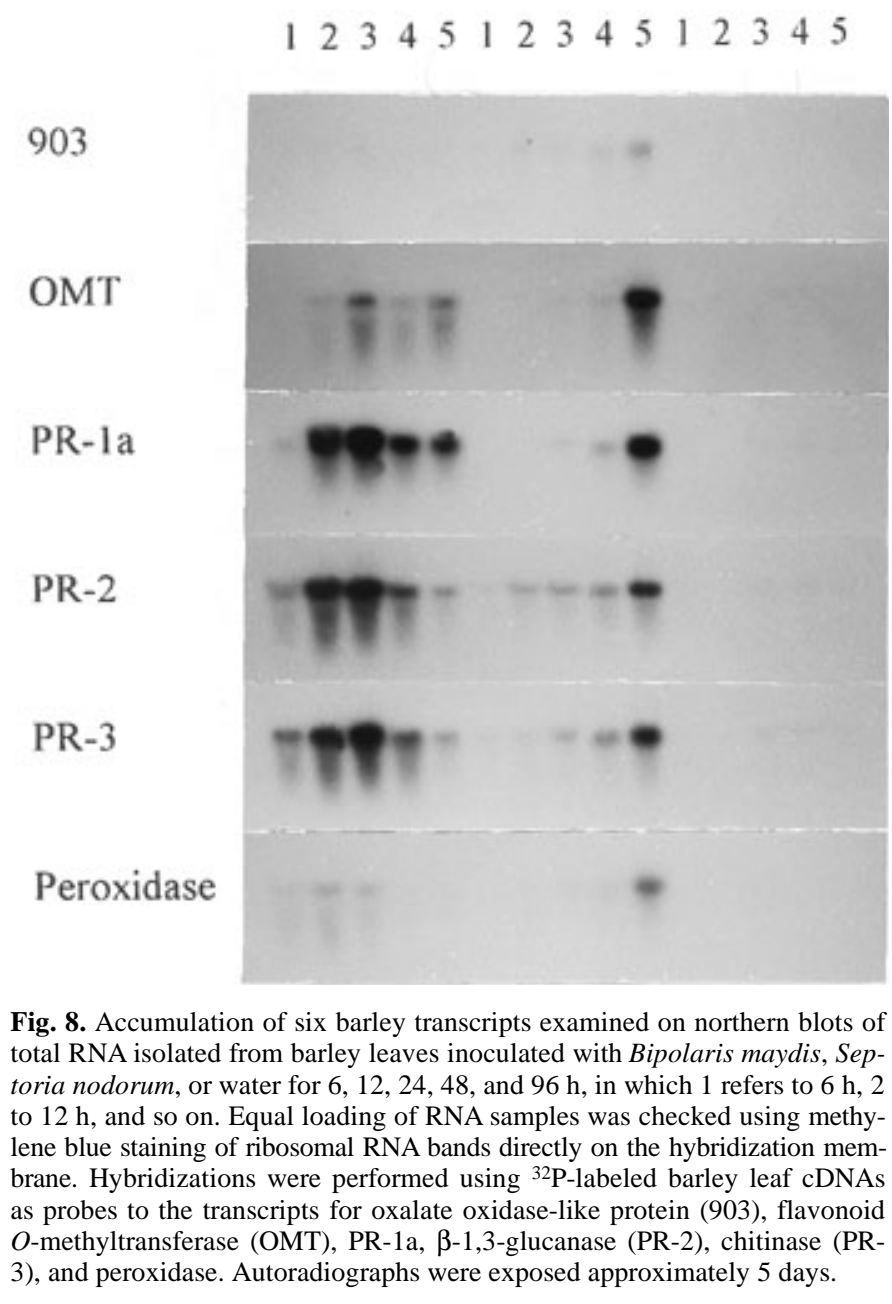
substances nor their impact on a necrotrophic pathogen like $D$. teres are known. The significant and consistently lower percentage of FEC in the inducer-treated than in the control leaves very likely is due to the reduced penetration of $D$. teres. This hypothesis is based on experiences from the barley-E. graminis f. sp. hordei system, in which it is generally considered that there is no FEC unless a cell is penetrated (cf. 1).

In the interaction between barley and E. graminis f. sp. hordei, a late type of multicellular resistance is sometimes expressed (20, $24,39,43)$. This form of resistance may be considered as a HR, although the necroses do not always completely stop fungal development $(20,39)$. The brown lesions we observed developing around penetration sites of $D$. teres, of course, represent the macroscopic symptoms of infection, being larger and more numerous (14) and causing more tissue damage in control than in inducer-treated plants. However, these lesions appear to be equivalent to the necrotic resistance lesions observed for E. graminis f. sp. hordei in barley, although further investigations are needed to examine this and their presumed origin from FEC. This hypothesis is based on the observation that hyphae of $D$. teres within the lesions in both inducer-treated and control plants were inhibited; they were thin and only sparsely stained, in contrast to the hyphae outside the lesions in control plants, which were thick and heavily stained. In the noninduced plants, hyphae spread rapidly and colonized the surrounding tissue, and eventually sporulation occurred. In the inducer-treated leaves, on the other hand, hyphal growth outside the lesions was almost nonexistent, sporulation was never seen, and tissue degradation was limited to the initial brown lesions. Although occurring in both inducer-treated and control plants, this presumed multicellular response is not strong enough to actually stop the invading pathogen in the noninduced leaves; however, inducer application enhances the effect, rendering the plant very resistant to fungal spread in the tissue and, thus, effectively stopping the growth from the few infections that were, in fact, established. Reduced number and size of lesions, together with reduced hyphal growth after penetration and reduced sporulation, were also found to be important in the expression of resistance of barley against $D$. teres by Keeling and Banttari (16), who suggested the involvement of antifungal substances in the inhibition of the pathogen.

Since B. maydis and $S$. nodorum cause formation of FP, FEC, and tissue necrosis, an attempt was made to monitor defense reactions in the barley leaves. This was done by studying a set of transcripts for which cDNA clones previously have been isolated in a differential screening program. The gene transcripts that accumulate during fungal pathogen attack are commonly observed in both compatible and incompatible plant-pathogen interactions (12). The transcripts for peroxidase, PR-2, and PR-3 have been shown previously to be expressed in barley leaves after inoculation with $D$. teres $(26,27)$. These results demonstrate that the transcripts accumulate not only in the defense against $E$. graminis f. sp. hordei, but also against $D$. teres. Since we found that accumulation of all six transcripts was induced by $B$. maydis and $S$. nodorum as well, it was suggested that inoculation of barley with these nonbarley pathogens induces defense reactions that may act against subsequent infection attempts by $D$. teres.

The strong and early accumulation of most HR-related transcripts (OMT, PR-1a, PR-2, and PR-3) by B. maydis reflects that this fungus causes a HR in the plant. The observation of many necrotic spots $24 \mathrm{~h}$ after inoculation with $B$. maydis is in agreement with the strong transcript accumulation observed in the northern blots at $24 \mathrm{~h}$.

S. nodorum did not cause any early necrotic spots in the plant, but sometimes a few spots were observed after $96 \mathrm{~h}$ (cf. 14). These spots probably reflect the late $(96 \mathrm{~h})$ and strong accumulation of hypersensitive-related transcripts caused by this fungus.

Both the B. maydis- and $S$. nodorum-induced resistances against $D$. teres are manifested as papilla resistance, which is in accordance with the albeit weak accumulation of the papilla-related oxalate oxidase-like transcript. The stronger accumulation of this transcript following inoculation with $S$. nodorum, compared with $B$. maydis, is in agreement with the ability of $S$. nodorum to induce intense papilla formation, although the high concentration of this inducer compared with $B$. maydis also must be taken into consideration. The slightly increasing induction of other transcripts related to papilla formation and $\mathrm{HR}$ (PR-2, PR-3, and peroxidase) by $S$. nodorum probably reflects the development of papilla over time, since HR seems to occur only after $96 \mathrm{~h}$.

In conclusion, our experiments strongly suggest that $D$. teres is inhibited by $B$. maydis and $S$. nodorum, primarily as a result of induced resistance. The histopathological data show that penetration and postpenetration growth of $D$. teres are inhibited in particular, and we provide possible explanations in agreement with the concept of induced resistance to account for this inhibition (increased formation of papillae and multicellular HR). The demonstration of transcript accumulation further substantiates this conclusion, since it shows that plant defense responses (papilla- and HR-specific transcripts) are activated by inoculation with the inducers. The plant thus becomes prepared to defend itself when inoculated with $D$. teres.

\section{ACKNOWLEDGMENTS}

This work was financed by the European Union through the CAMAR project: "Crop Protection Using Diversification and Induced Resistance in Low-Input Cereal/Legume Cropping Systems". We thank H. Stryhn, Department of Mathematics and Physics, The Royal Veterinary and Agricultural University, Copenhagen, for statistical advice; and L. Jensen and A. M. Nørskov for technical assistance.

\section{LITERATURE CITED}

1. Aist, J. R., and Bushnell, W. R. 1991. Invasion of plants by powdery mildew fungi, and cellular mechanisms of resistance. Pages 321-345 in: The Fungal Spore and Disease Initiation in Plants and Animals. G. T. Cole and H. C. Hoch, eds. Plenum Press, New York.

2. Arase, S., and Fujita, K. 1992. Induction of inaccessibility to Pyricularia oryzae by pre-inoculation of $P$. grisea in rice leaf-sheath cells. J. Phytopathol. 134:97-102.

3. Asher, M. J. C., and Thomas, C. E. 1983. The expression of partial resistance to Erysiphe graminis in spring barley. Plant Pathol. 32:79-89.

4. Bird, P. M., and Ride, J. P. 1981. The resistance of wheat to Septoria nodorum: Fungal development in relation to host lignification. Physiol. Plant Pathol. 19:289-299.

5. Bryngelsson, T., Sommer-Knudsen, J., Gregersen, P. L., Collinge, D. B., Ek, B., and Thordal-Christensen, H. 1994. Purification, characterization, and molecular cloning of basic PR-1-type pathogenesis-related proteins from barley. Mol. Plant-Microbe Interact. 7:267-275.

6. Collett, D. 1991. Modelling Binary Data. Chapman \& Hall, London.

7. Collinge, D. B., Milligan, D. E., Dow, J. M., Scofield, G., and Daniels, M. J. 1987. Gene expression in Brassica campestris showing a hypersensitive response to the incompatible pathogen Xanthomonas campestris pv. vitians. Plant Mol. Biol. 8:405-414.

8. Cox, D. R., and Snell, E. J. 1989. Analysis of Binary Data 2nd ed. Monographs on Statistics and Applied Probability, Vol. 32. Chapman \& Hall, London.

9. Coyle, P. M., and Cooke, B. M. 1993. Scanning electron micrographs of barley leaves infected with Drechslera teres. Mycologist 7:109-111.

10. Gregersen, P. L., Christensen, A. B., Sommer-Knudsen, J., and Collinge, D. B. 1994. A putative $O$-methyltransferase from barley is induced by fungal pathogens and UV light. Plant. Mol. Biol. 26:1797-1806.

11. Gregersen, P. L., Collinge, D. B., and Smedegaard-Petersen, V. 1990. Early induction of new mRNAs accompanies the resistance reaction of barley to the wheat pathogen, Erysiphe graminis f. sp. tritici. Physiol. Mol. Plant Pathol. 36:471-481.

12. Gregersen, P. L., Thordal-Christensen, H., Förster, H., and Collinge, D. B. 1997. Differential gene transcript accumulation in barley leaf epidermis and mesophyll in response to attack by Blumeria graminis f. sp. hordei (syn. Erysiphe graminis f. sp. hordei). Physiol. Mol. Plant Pathol. 51:85-97.

13. Heath, M. C., Valent, B., Howard, R. J., and Chumley, F. G. 1990. Interactions of two strains of Magnaporthe grisea with rice, goosegrass, and weeping lovegrass. Can. J. Bot. 68:1627-1637.

14. Jørgensen, H. J. L., Andresen, H., and Smedegaard-Petersen, V. 1996. Control of Drechslera teres and other barley pathogens by preinocula- 
tion with Bipolaris maydis and Septoria nodorum. Phytopathology 86: 602-607.

15. Jørgensen, H. J. L., de Neergaard, E., and Smedegaard-Petersen, V. 1993. Histological examination of the interaction between Rhynchosporium secalis and susceptible and resistant cultivars of barley. Physiol. Mol. Plant Pathol. 42:345-358.

16. Keeling, B. L., and Banttari, E. E. 1975. Factors associated with the resistance of barley to Helminthosporium teres. Phytopathology 65:464-467.

17. Keon, J. P. R., and Hargreaves, J. A. 1983. A cytological study of the net blotch disease of barley caused by Pyrenophora teres. Physiol. Plant Pathol. 22:321-329.

18. Kita, N., Toyoda, H., and Shishiyama, J. 1981. Chronological analysis of cytological responses in powdery-mildewed barley leaves. Can. J. Bot. 59:1761-1768.

19. Kloepper, J. W., Tuzun, S., and Kuć, J. A. 1992. Proposed definitions related to induced disease resistance. Biocontrol Sci. Technol. 2:349-351.

20. Koga, H., Mayama, S., and Shishiyama, J. 1978. Microscopic specification of compatible and incompatible interactions in barley leaves inoculated with Erysiphe graminis hordei. Ann. Phytopathol. Soc. Jpn. 44:111-119.

21. Koga, H., Zeyen, R. J., Bushnell, W. R., and Ahlstrand, G. G. 1988. Hypersensitive cell death, autofluorescence, and insoluble silicon accumulation in barley leaf epidermal cells under attack by Erysiphe graminis f. sp. hordei. Physiol. Mol. Plant Pathol. 32:395-409.

22. Lehnackers, H., and Knogge, W. 1990. Cytological studies on the infection of barley cultivars with known resistance genotypes by Rhynchosporium secalis. Can. J. Bot. 68:1953-1961.

23. Manandhar, H. K. 1996. Rice Blast Disease. Seed Transmission and Induced Resistance. Ph.D. thesis. Department of Plant Biology, The Royal Veterinary and Agricultural University, Copenhagen, Denmark.

24. Mayama, S., and Shishiyama, J. 1976. Histological observation of cellular responses of barley leaves to powdery mildew infection by UVfluorescence microscopy. Ann. Phytopathol. Soc. Jpn. 42:591-596.

25. Mumford, D. L. 1966. Factors associated with resistance in barley to spot blotch. Phytopathology 56:79-82.

26. Møller, I. 1992. Resistance in Barley to the Net Blotch Fungus, Pyrenophora teres. Ph.D. thesis. Department of Plant Biology, The Royal Veterinary and Agricultural University, Copenhagen, Denmark.

27. Reiss, E., and Bryngelsson, T. 1996. Pathogenesis-related proteins in barley leaves, induced by infection with Drechslera teres (Sacc.) Shoem. and by treatment with other biotic agents. Physiol. Mol. Plant Pathol. 49:331-341.

28. Sahashi, N., and Shishiyama, J. 1986. Increased papilla formation, a major factor of induced resistance in the barley-Erysiphe graminis f. sp. hordei system. Can. J. Bot. 64:2178-2181.

29. Sambrook, J., Fritsch, E. F., and Maniatis, T. 1989. Molecular Cloning: A Laboratory Manual. 2nd ed. Cold Spring Harbor Laboratory Press, Cold Spring Harbor, NY.

30. Sherwood, R. T., and Vance, C. P. 1980. Resistance to fungal penetration in Gramineae. Phytopathology 70:273-279.

31. Smedegaard-Petersen, V., Brandt, J., Cho, B. H., Collinge, D. B., Gregersen, P. L., and Thordal-Christensen, H. 1991. Molecular and energetic aspects of induced resistance in barley. Pages 123-134 in: Proc. Int. Symp. Biotic Stress Barley Arid Semi-Arid Environ. J. Riesselman, ed. Montana State University, Bozeman, and ICARDA (International Center for Agricultural Research in Dry Areas), Aleppo, Syria.

32. Smedegaard-Petersen, V., Collinge, D. B., Thordal-Christensen, H., Brandt, J., Gregersen, P. L., Cho, B. H., Walther-Larsen, H., Kristensen,
H. J., and Vad, K. 1992. Induction and molecular analyzes of resistance to barley powdery mildew. Pages 321-326 in: Biological Control of Plant Diseases: Progress and Challenges for the Future. NATO ASI Series. Series A, Life Sciences; Vol. 230. E. C. Tjamos, G. C. Papavizas, and R. J. Cook, eds. Plenum Press, New York.

33. Smith, J. A., and Métraux, J.-P. 1991. Pseudomonas syringae pv. syringae induces systemic resistance to Pyricularia oryzae in rice. Physiol. Mol. Plant Pathol. 39:451-461.

34. Sprent, P. 1989. Applied Nonparametric Statistical Methods. Chapman \& Hall, London.

35. Stanbridge, B., Gay, J. L., and Wood, R. K. S. 1971. Gross and fine structural changes in Erysiphe graminis and barley before and during infection. Pages 367-379 in: Ecology of Leaf Surface Micro-Organisms. T. F. Preece and C. H. Dickinson, eds. Academic Press, London.

36. Steiner, U., and Schönbeck, F. 1995. Induced disease resistance in monocots. Pages 86-110 in: Induced Resistance to Disease in Plants. R. Hammerschmidt and J. Kuć, eds. Kluwer Academic Publishers, Dordrecht, the Netherlands.

37. Thordal-Christensen, H., Brandt, J., Cho, B. H., Rasmussen, S. K., Gregersen, P. L., Smedegaard-Petersen, V., and Collinge, D. B. 1992. cDNA cloning and characterization of two barley peroxidase transcripts induced differentially by the powdery mildew fungus Erysiphe graminis. Physiol. Mol. Plant Pathol. 40:395-409.

38. Thordal-Christensen, H., and Smedegaard-Petersen, V. 1988. Correlation between induced resistance and host fluorescence in barley inoculated with Erysiphe graminis. J. Phytopathol. 123:34-46.

39. Toyoda, H., Mayama, S., and Shishiyama, J. 1978. Fluorescent microscopic studies on the hypersensitive necrosis in powdery-mildewed barley leaves. Phytopathol. Z. 92:125-131.

40. Van Caeseele, L., and Grumbles, J. 1979. Ultrastructure of the interaction between Pyrenophora teres and a susceptible barley host. Can. J. Bot. 57:40-47.

41. Vance, C. P., and Sherwood, R. T. 1976. Cycloheximide treatments implicate papilla formation in resistance of reed canarygrass to fungi. Phytopathology 66:498-502.

42. Vance, C. P., and Sherwood, R. T. 1977. Lignified papilla formation as a mechanism for protection in reed canarygrass. Physiol. Plant Pathol. 10:247-256.

43. Wei, Y. D., de Neergaard, E., Thordal-Christensen, H., Collinge, D. B., and Smedegaard-Petersen, V. 1994. Accumulation of a putative guanidine compound in relation to other early defense reactions in epidermal cells of barley and wheat exhibiting resistance to Erysiphe graminis f. sp. hordei. Physiol. Mol. Plant Pathol. 45:469-484.

44. Wei, Y. D., Zhang, Z., Andersen, C. H., Schmelzer, E., Gregersen, P. L., Collinge, D. B., Smedegaard-Petersen, V., and Thordal-Christensen, H., 1998. An epidermis/papilla-specific oxalate oxidase-like protein in the defence response of barley attacked by the powdery mildew fungus. Plant Mol. Biol. 36:101-112.

45. Wright, A. J., and Heale, J. B. 1988. Host responses to fungal penetration in Erysiphe graminis f. sp. hordei infections in barley. Plant Pathol. 37:131-140.

46. Zeyen, R. J., Bushnell, W. R., Carver, T. L. W., Robbins, M. P., Clark, T. A., Boyles, D. A., and Vance, C. P. 1995. Inhibiting phenylalanine ammonia lyase and cinnamyl-alcohol dehydrogenase suppresses Mlal (HR) but not mlo5 (non-HR) barley powdery mildew resistances. Physiol. Mol. Plant Pathol. 47:119-140. 